OPEN ACCESS

Edited by: Lars Bejder,

University of Hawai'i at Mānoa, United States

Reviewed by:

James Higham,

University of Otago, New Zealand

Daniel M. Palacios,

Oregon State University,

United States

*Correspondence: Pedro Morais pmorais@ualg.pt

Specialty section:

This article was submitted to

Marine Megafauna,

a section of the journal

Frontiers in Marine Science

Received: 26 August 2021 Accepted: 14 September 2021

Published: 16 November 2021

Citation:

Morais $P$, Afonso $L$ and Dias $E$

(2021) Harnessing the Power

of Social Media to Obtain Biodiversity

Data About Cetaceans in a Poorly

Monitored Area.

Front. Mar. Sci. 8:765228.

doi: 10.3389/fmars.2021.765228

\section{Harnessing the Power of Social Media to Obtain Biodiversity Data About Cetaceans in a Poorly Monitored Area}

\author{
Pedro Morais ${ }^{1,2 *}$, Luís Afonso ${ }^{3}$ and Ester Dias ${ }^{3}$ \\ ${ }^{1}$ Centre of Marine Sciences (CCMAR), Universidade do Algarve, Faro, Portugal, ${ }^{2}$ Institute of Environment, Florida \\ International University, Miami, FL, United States, ${ }^{3}$ CIMAR/CIMAR-Interdisciplinary Centre of Marine and Environmental \\ Research, University of Porto, Matosinhos, Portugal
}

The study and conservation of cetaceans benefit from systematic studies and nonsystematic records about sightings and strandings. However, iEcology (internet ecology) was critical for numerous ecological studies and should be in the toolkit of cetacean ecologists. We hypothesize that iEcology is irreplaceable to obtain diversity data about cetaceans in poorly monitored regions that coincide with touristic destinations, where whale-watching companies go out to sea regularly and post their sightings on social media. Our study assessed the advantages and disadvantages of iEcology while obtaining the first broadscale and long-term assessment about cetaceans' diversity off the Algarve, a European tourist destination with numerous whale-watching companies. We retrieved 1,299 time-referenced records about 15 species posted on Facebook and Instagram between 2011 and 2020. Data collected from Biodiversity4All, an online citizen science biodiversity database, disclosed georeferenced records about nine species made between 2008 and 2020, however, the number of records was 15.8 times lower than social media posts. We obtained information about 16 species, two of which were never mentioned in the scientific literature [Balaenoptera musculus, Balaenoptera edeni (record made in 2021)] and five species were only mentioned in the gray literature. Previous assessments were restricted in time, published in the gray literature, and only reported six and 11 species. So, social media was essential to obtain the first broadscale and long-term assessment of cetaceans' diversity off the Algarve. The main advantages of iEcology were the possibility to obtain data collected over one decade and its low cost. The main disadvantages are the impossibility to obtain georeferenced records from social media, the difficulty to estimate the number of individuals in large groups, and the presence of rare species can be inflated if multiple whale-watching companies report the same individual(s) while they migrate along the coast. Nonetheless, these disadvantages can be mitigated. Overall, we endorse the use of iEcology to increase the ecological knowledge about cetaceans which might be the only tool to study them in numerous regions across the world. The contributions of whale-watching companies are invaluable, so we recommend the implementation of a standardized cetacean observation log as a relevant source of data for conservation. 


\section{INTRODUCTION}

Social media has progressively changed how humans interact in the digital landscape, while morphing societies at a fast pace leaving no aspect untouched, including science (Aichner et al., 2021). Social media has evolved over the past decades (Aichner et al., 2021) and is now defined as internet-based applications with user-generated content maintained by the social media service provider which facilitate the development of online networks between individuals or group users (Obar and Wildman, 2015). The most used social media platforms in the world, like Facebook or Instagram, provide generalist platforms for people to interact with acquaintances and others around common interests, or for organizations to convey their messages or sell their products. On the other hand, specialized platforms focus on specific subjects, including biodiversity (e.g., iNaturalist, GBIF- Global Biodiversity Information Facility), therefore being extremely effective in reaching their potential audience despite having a smaller overall audience.

The ever-growing digital data originated from social media and specialized biodiversity platforms have given rise to iEcology (internet ecology) which is expected to become more and more prevalent (Jarić et al., 2020). This new discipline has been defined as an "approach that uses diverse online data sources and methods to generate insights about species distribution over space and time, interactions and dynamics of organisms and their environment, and anthropogenic impacts" (Jarić et al., 2020). iEcology has advantages and disadvantages. Two of the main advantages are it's low-cost for users and the broad geographic scope of the ecological insights that can be obtained (Jarić et al., 2020; Encarnação et al., 2021a,b). On the other hand, species misidentification, focus on charismatic or rare species, and nonrandom collection of data are some of the disadvantages that iEcologists need to be aware of Jarić et al. (2020). While the posts of general social media platforms can focus on charismatic or rare species, this tends to dilute partially when analyzing data from biodiversity platforms where naturalists or professional ecologists share their observations. One of the most prolific biodiversity platforms is iNaturalist, a biodiversity social media platform with over one million naturalists and scientists registered, where georeferenced photographs of all sorts of species are posted and species identifications are validated by peers (iNaturalist, 2021).

Social media can provide timely information about numerous topics, from public health (Lopreite et al., 2021) to nonindigenous (Azzurro and Tiralongo, 2020) and invasive species (Daume, 2016; Encarnação et al., 2021a), or it can be mined to obtain retrospective ecological assessments (Toivonen et al., 2019). Traditionally, the study and conservation of cetaceans have benefited from systematic records using a multitude of tools aboard scientific ships/aircraft and ships of opportunity (Hammond et al., 2013; Alves et al., 2018; Correia et al., 2021) and from non-systematic records about sightings and strandings (Evans and Hammond, 2004; Li et al., 2021). Nowadays, iEcology is another tool that should be included in the toolkit of cetacean ecologists while being perfected. Some successful examples include the photo-identification of Tursiops truncatus in the Irish coast (Gibson et al., 2020) and obtaining estimates of changes in population density of Delphinus delphis based on stranded specimens (Robbins et al., 2020). Also, social media records about the presence/absence of cetaceans in the central Tyrrhenian Sea between 2008 and 2017 led to the recommendation of conservation policies (Pace et al., 2019), while in Kenya, a combination of multiple methodologies (dedicated surveys, opportunistic sightings, citizen science) successfully retrieved information about marine mammals over 9 years (Mwango'mbe et al., 2021). Therefore, we hypothesize that iEcology can become particularly useful to study cetaceans in touristic areas, where cetacean watching companies (hereafter referred to as whalewatching) go out to sea regularly and post their sightings on social media. The Algarve, a major European touristic area located in southern Portugal, is the ideal area to test this hypothesis because of the numerous whale-watching companies that exist (Claro, 2009; Sequeira et al., 2009) and the small number of formal scientific studies that have been undertaken in the region.

In the Algarve, a long-term monitoring program has never been implemented which is crucial for any robust conservation program. So far, the two most comprehensive studies made about the abundance and distribution of cetaceans in the Algarve are only published as gray literature (Castro, 2010; Laborde et al., 2019). One study registered the presence of six species along a $\sim 30 \mathrm{~km}$ coast stretch in the western Algarve during a little over 8 months (Castro, 2010), while the other study reported the presence of 11 species along the entire region during 6-month periods over 10 years (Laborde et al., 2019). Existing knowledge is mostly published as gray literature, while peer-reviewed publications are scarce and have focused on strandings (Silva and Sequeira, 2003; Sousa and Brito, 2012), aspects of population connectivity (Alves et al., 2019; Dinis et al., 2021) the population ecology of Delphinus delphis (Moura et al., 2012; Castro et al., 2020), and Orcinus orca (Esteban et al., 2013) description of opportunistic observations (Martin and Walker, 1997; Báez et al., 2007), interaction with fisheries (Goetz et al., 2015; Marçalo et al., 2015), diet (Marçalo et al., 2018, 2021) or diet/trophic ecology (Giménez et al., 2017), behavioral responses to drones (Castro et al., 2021), and epidemiology (Bento et al., 2016).

So, our main goal was to use the social media posts of whale-watching companies located in the Algarve to test our hypothesis and obtain the first broadscale and long-term assessment about cetaceans' biodiversity off the Algarve. We also have three complementary objectives: (i) enumerate the advantages and disadvantages of iEcology to study cetaceans; (ii) compare data from general social media platforms (Facebook, Instagram) and Biodiversity4All to understand if data from these two major sources complement each other; and (iii) propose a methodology to improve and increase the data collected by whale-watching companies.

\section{MATERIALS AND METHODS}

\section{Study Area and Whale-Watching}

The Algarve is the southern region of Portugal (Europe) and its southern coast extends for $155 \mathrm{~km}$. The eastern area is mostly a sandy coast, only interrupted by the Ria Formosa lagoon and its barrier islands, while the central and western areas are characterized by limestone and sandstone rocky shores 


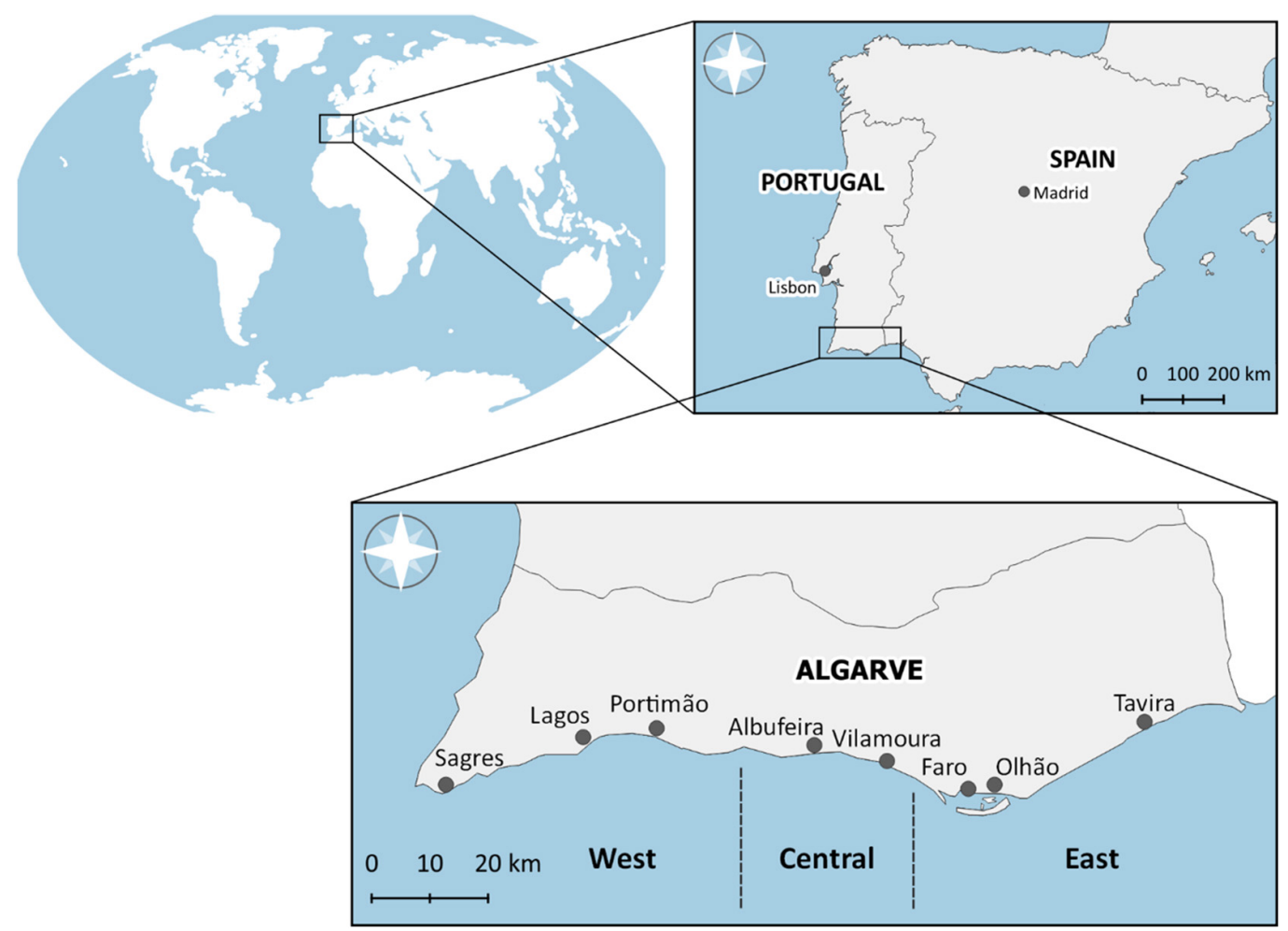

FIGURE 1 | Main cities and villages along the coast of the Algarve (Portugal, Europe) where the whale-watching companies analyzed in this study are located (see Table 1 for details).

along with pocket sandy beaches and cliffs toward western areas (Moura et al., 2006). The continental platform is wider to the east of Cape Santa Maria (Faro) $(>40 \mathrm{~km}$ ) and with a gentle slope, while it narrows down toward Cape Saint Vincent (Sagres) $(<15 \mathrm{~km})$. Here, the slope is steep, and depths of $100 \mathrm{~m}$ can be reached within $10 \mathrm{~km}$ from the coast (Relvas and Barton, 2002).

The Algarve is the center of the whale-watching industry in Portugal's mainland (Sequeira et al., 2009), an industry that began to operate in 1999 in the Sado estuary $(30 \mathrm{~km}$ south of Lisbon). The Algarve's whale-watching industry is highly seasonal, with most of the activity occurring from late spring to early fall, nonetheless, some companies operate year-round. In 2018, 35 whale-watching permits were authorized to touristic operators in the Algarve which used 83 boats. A code of best practices to safeguard the wellbeing of cetaceans during the approach and observation of cetaceans is stipulated in decree-law 9/2006 (Governo de Portugal, 2006). This decreelaw includes guidelines on the distance that must be kept between the boat and animals during approximation (over $30 \mathrm{~m}$ if cetaceans do not actively approach the boat), distance and number of boats allowed near an individual or group of individuals during observation (no more than three boats within a radius of $100 \mathrm{~m}$ from cetaceans), duration of the observation (less than $30 \mathrm{~min}$ when closer than $100 \mathrm{~m}$ ), and procedures to perform when cetaceans exhibit stress behaviors (boats must move at least $300 \mathrm{~m}$ away from cetaceans) (Governo de Portugal, 2006). Although it is difficult to verify if the law is being implemented to its full extent by the whale-watching companies, a study already published in 2009 mentions that 66\% of customers believed that the regulations were implemented during their trip (Claro, 2009). However, a study done in the region observed that Tursiops truncatus exhibits stress reactions to the presence of boats, particularly as the number of boats increases (MacEwan et al., 2016).

\section{Social Media Data}

Facebook and Instagram are the social media platforms most used in Portugal, including by whale-watching companies in the Algarve. First, we collected data about which of these companies used Facebook and Instagram to post information about the species they encountered during tours. Those companies that only posted promotional material without time-referenced posts were not considered in our analysis. This has left us with 15 companies that made time-referenced social media posts of cetaceans observed off the Algarve (Figure 1 and Table 1). Then, we retrieved information from every single social media post (photographs and videos) and excluded from the analysis the promotional posts that were not time-referenced. We collected information about the species, date of observation, the minimum number of individuals, and the area where the observation was made in the Algarve (west, central, east). The species identification mentioned in the post description was always confirmed by us.

We calculated the Qualitative Commonness Index (QC Index, $\%)$ to assess how common each species was. The QC Index is the ratio between the number of records of species $i\left(S_{i \_n}\right)$ and the 
TABLE 1 | List of whale-watching companies located in the Algarve (Portugal) with active social media accounts on Facebook and Instagram in December 2020, and the number of time-referenced posts published by each company since their first post on social media.

\begin{tabular}{|c|c|c|c|}
\hline $\begin{array}{l}\text { Whale-watching } \\
\text { companies }\end{array}$ & $\begin{array}{l}\text { Location and } \\
\text { area of the } \\
\text { Algarve }\end{array}$ & $\begin{array}{l}\text { First post on } \\
\text { social media }\end{array}$ & $\begin{array}{c}\text { Number of } \\
\text { posts }\end{array}$ \\
\hline Cape Cruiser & Sagres-west & June 2012 & 171 \\
\hline Days of Adventure & Lagos - west & August 2012 & 60 \\
\hline Dolphins Driven & Albufeira-central & July 2011 & 68 \\
\hline Ecomarine & Faro-east & June 2017 & 33 \\
\hline Mar llimitado & Sagres-west & May 2016 & 198 \\
\hline $\begin{array}{l}\text { Ocean Quest } \\
\text { Algarve }\end{array}$ & Vilamoura-central & April 2018 & 40 \\
\hline Ocean Vibes & Faro-east & August 2019 & 49 \\
\hline Ocean4you & Tavira-east & July 2016 & 10 \\
\hline $\begin{array}{l}\text { Passeios Ria } \\
\text { Formosa }\end{array}$ & Olhão-east & February 2014 & 33 \\
\hline Rota das Ilhas Boat & Olhão-east & June 2018 & 28 \\
\hline Sabino Tours & Olhão-east & August 2015 & 27 \\
\hline Sea Dolphins & Portimão-west & March 2018 & 34 \\
\hline $\begin{array}{l}\text { Sealife Dolphin } \\
\text { Watching }\end{array}$ & Lagos-west & June 2016 & 135 \\
\hline SeaXplorer & Sagres-west & April 2016 & 222 \\
\hline Wild Watch Algarve & Portimão-west & May 2013 & 191 \\
\hline
\end{tabular}

number of records of the species with most social media posts $\left(S_{n \_ \text {max }}\right)$ (Equation 1).

$$
\text { QC Index }=\frac{S_{i \_n}}{S_{n \_ \text {max }}} \times 100(1)
$$

Species were classified into four categories, rare ([0-5\%], uncommon ([5-50\%]), common ([50-80\%], and frequent ([80$100 \%])$. We also estimated the minimum number of individuals present in a social media post when the exact number of individuals from a given species was impossible to determine from a photograph or video. This strategy was mainly used to estimate the minimum number of the most common dolphin species in the Algarve, Delphinus delphis, and Tursiops truncatus.

\section{Citizen Science Data}

All data about the cetaceans observed off the Algarve coast available on Biodiversity4All (2021) was retrieved and comprised of all records made between 2008 and 2020. This is a citizen science biodiversity platform available in Portuguese and synchronized with sibling platforms under the iNaturalist.org consortium. Each record contains a photo, date of observation, and is georeferenced. Data were analyzed according to the year of observation, species, and location.

\section{RESULTS}

\section{Social Media}

A total of 1403 records were retrieved from observations made by 15 whale-watching companies from 2011 to 2020. The majority of social media posts were time-referenced $(92.2 \%, n=1,299)$, made reference to a single species $(83.7 \%, n=1,180)$ (Figure 2A), and ranged from 1 post in 2011 to 306 posts in 2018 (Figure 2B). Facebook was the platform where most posts were made $(51.6 \%$, $n=670)$, but its preponderance decreased along time from $100 \%$ in $2011(n=1)$ and $2012(n=12)$ to $34.7 \%(n=114)$ in 2018 as the number of posts on Instagram increased $\left(n_{\max }=215(65.4 \%)\right.$ in 2018) (Figure 2B).

The number of posts peaked in $2018(25.3 \%, n=329)$ (Figures 2B, 3A) and most observations were made in the western region of the Algarve $(77.8 \%, n=1,011)$ (Figure 3) and during the main touristic season (June through September) $(65.2 \%, n=847)$ (Figure 3B). The number of social media posts was lower in the central $(8.3 \%, n=108)$ and eastern Algarve $(13.9 \%, n=180)$ during the winter and early spring (DecemberApril, $11.8 \%, n=153$ ). A total of 15 cetacean species were registered along the Algarve coast: nine odontocetes and five mysticetes, one of which was only mentioned in a promotional post made by Cape Cruiser (western Algarve) in 2014 without being time-referenced-sperm whale Physeter macrocephalus. The three most common species on social media posts were Delphinus delphis $(43.8 \%, n=569)$, Tursiops truncatus $(29.6 \%$, $n=384)$, and Orcinus orca $(5.1 \%, n=66)$ (Figure 3C). When analyzing the relative frequency of Delphinus delphis and Tursiops truncatus in each area of the Algarve, their contribution varied between $42.6-49.4 \%$ and 26.3-49.1\%, respectively (Figure 3D). Unsurprisingly, odontocetes were the most common group depicted in social media posts $(90.4 \%, n=1,174$; mysticetes- $9.6 \%$, $n=125$ ) (Figure 3E).

According to the QC Index categories defined for this work, Delphinus delphis was classified as frequent while Tursiops truncatus was classified as common, although both were observed year-round. Five species were classified as uncommon (Balaenoptera acutorostrata, Balaenoptera physalus, Grampus griseus, Orcinus orca, Stenella coeruleoalba) with the relative number of records ranging from 9.5 to $11.6 \%$ of the total, while seven species were rare (Balaenoptera borealis, Balaenoptera musculus, Globicephala macrorhynchus, Globicephala melas, Megaptera novaeangliae, Phocoena phocoena, Pseudorca crassidens) with the number of records ranging from 0.2 to $3.2 \%$ of the total (Figure 3C).

The highest means ( \pm standard error; median, $n$ ) of the minimum number of individuals registered in each record were $14.1 \pm 2.2($ median $=4, n=569)$ for Delphinus delphis, $12.9 \pm 4.8$ (median $=2, n=65)$ for Stenella coeruleoalba, and $4.6 \pm 0.4$ (median $=3, n=384$ ) for Tursiops truncatus (Figure 4). The maximum sum of the minimum number of individuals registered on social media posts in a month was 33 individuals for Delphinus delphis (August 2019) and 19 individuals for Tursiops truncatus (August 2019 and July 2020) (Figure 5). The rarest species, with only one individual reported between 2011 and 2020 were Balaenoptera borealis, Balaenoptera musculus, Globicephala macrorhynchus, and Pseudorca crassidens (Figure 5).

\section{Citizen Science Data}

A total of 82 observations of nine species of cetaceans were registered on Biodiversity4All. Three observations corresponded 


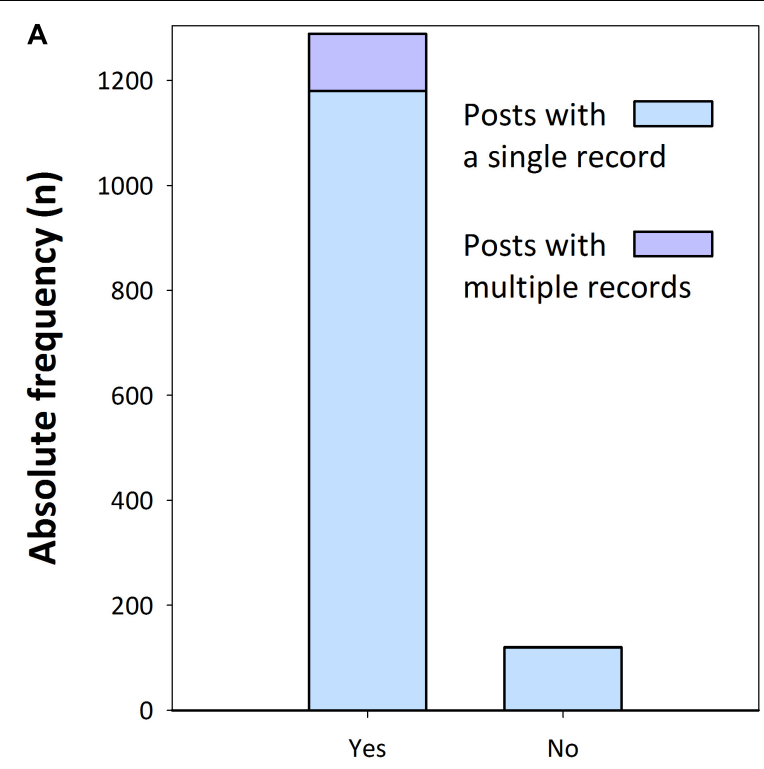

Time referenced records

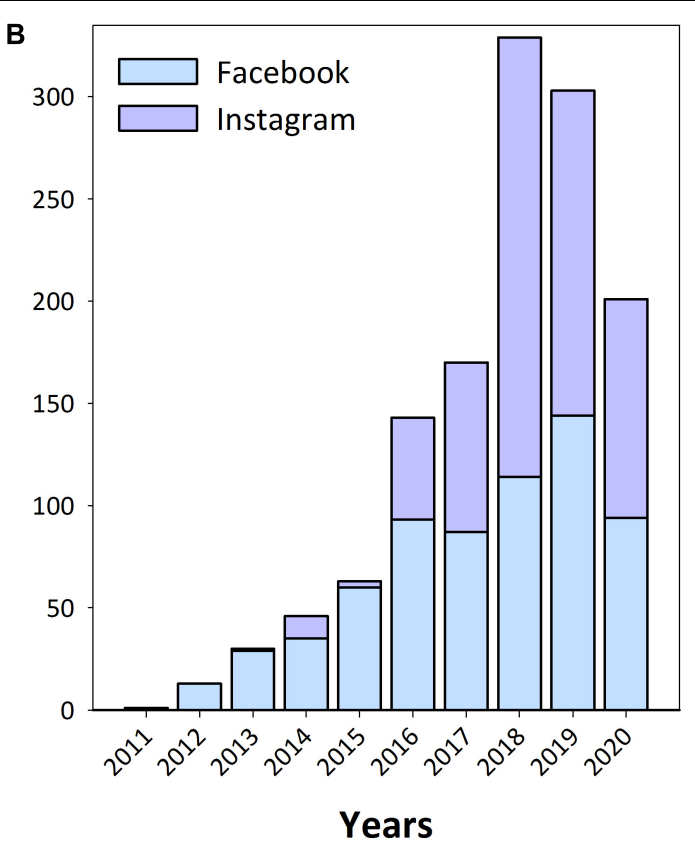

FIGURE 2 | Number of time-referenced vs. non-time-referenced social media posts on Facebook and Instagram made in the accounts of whale-watching companies from the Algarve (Portugal) between 2011 and 2020, and taking in consideration if a single record or multiple records were made in each post (A), and evolution of time-referenced posts along time (B).

to stranded individuals-Balaenoptera acutorostrata (Altura on Jan 27, 2020), Delphinus delphis (Olhão on July 7, 2020, and Faro on July 14, 2020) (Figure 6A). The number of observations peaked in $2020(n=28,34.1 \%)$ (Figure 6B) and most records were made in August $(n=18,22.0 \%)$ and October $(n=19,23.2 \%)$ (Figure 6C). Most observations registered were of Tursiops truncatus $(n=32,39.0 \%)$ and Delphinus delphis $(n=28,34.1 \%)$ (Figures 6D,E). Six species of odontocetes were registered and were also the most common group of cetaceans observed ( $n=76$, $92.7 \%)$, while only three species of mysticetes were registered ( $n=6,7.3 \%$ ) (Figure 6F). Regarding the minimum number of individuals registered in each record, $95.1 \%$ of the records (78 out of 82) varied between 1 and 14 individuals. Larger groups of individuals belonged to three species Stenella coeruleoalba (estimate of 1,500 individuals, July 2020, off Faro), Delphinus delphis (estimate of 1,000 and 400 individuals, September 2020 and October 2019, both off Faro), and Tursiops truncatus (estimate of 150 individuals, August 2019, off Olhão) (Figure 7).

\section{DISCUSSION}

This study proved the value of iEcology in obtaining fundamental data about cetaceans in a poorly studied region, i.e., spatial and temporal information, presence/absence of species. In the following sections, we provide details that support the value of iEcology to cetacean research, mention its caveats, and recommend a strategy to maximize the information acquired by whale-watching companies during cruises and how it could benefit research and conservation.

\section{Diversity of Cetaceans Off the Algarve}

We successfully retrieved spatial and temporal information from the social media of whale-watching companies about 15 cetacean species present or migrating along the coast of the Algarve. The fact that the Algarve is a touristic area certainly contributed to this success. For example, a nationwide approach to monitor marine mammals in Kenya, which used other methodologies (dedicated surveys, opportunistic sightings, citizen science) gathered 792 records over 9 years (2011-2019) (Mwango'mbe et al., 2021). In Italy, 1274 records obtained from Facebook and YouTube during 10 years (2008-2017) disclosed information about the presence/absence of species and habitat selection along a $370 \mathrm{~km}$ stretch of the coast in the Tyrrhenian Sea (Pace et al., 2019). In an identical period, the Algarve's whale-watching companies published 1299 time-referenced records on social media during 10 years (1098 records from 2011 to 2019) and along a coastline approximately one-third the size of the Kenyan coast (Mwango'mbe et al., 2021) and part of the examined Tyrrhenian Sea coast (Pace et al., 2019).

Among the records of 15 species that were retrieved from social media between 2011 and 2020, four species were never described in the scientific literature for the Algarve (Balaenoptera borealis, Balaenoptera musculus, Megaptera novaeangliae, Pseudorca crassidens) (Table 2). Another species that was never mentioned in the scientific literature was Balaenoptera edeni which was reported on social media by a whale-watching company on August 23, 2021 (Ocean Vibes Algarve, 2021). Although this record was not made during the temporal scope of this study, we included this species in the list of cetacean species of the Algarve due to its uniqueness and therefore raising 


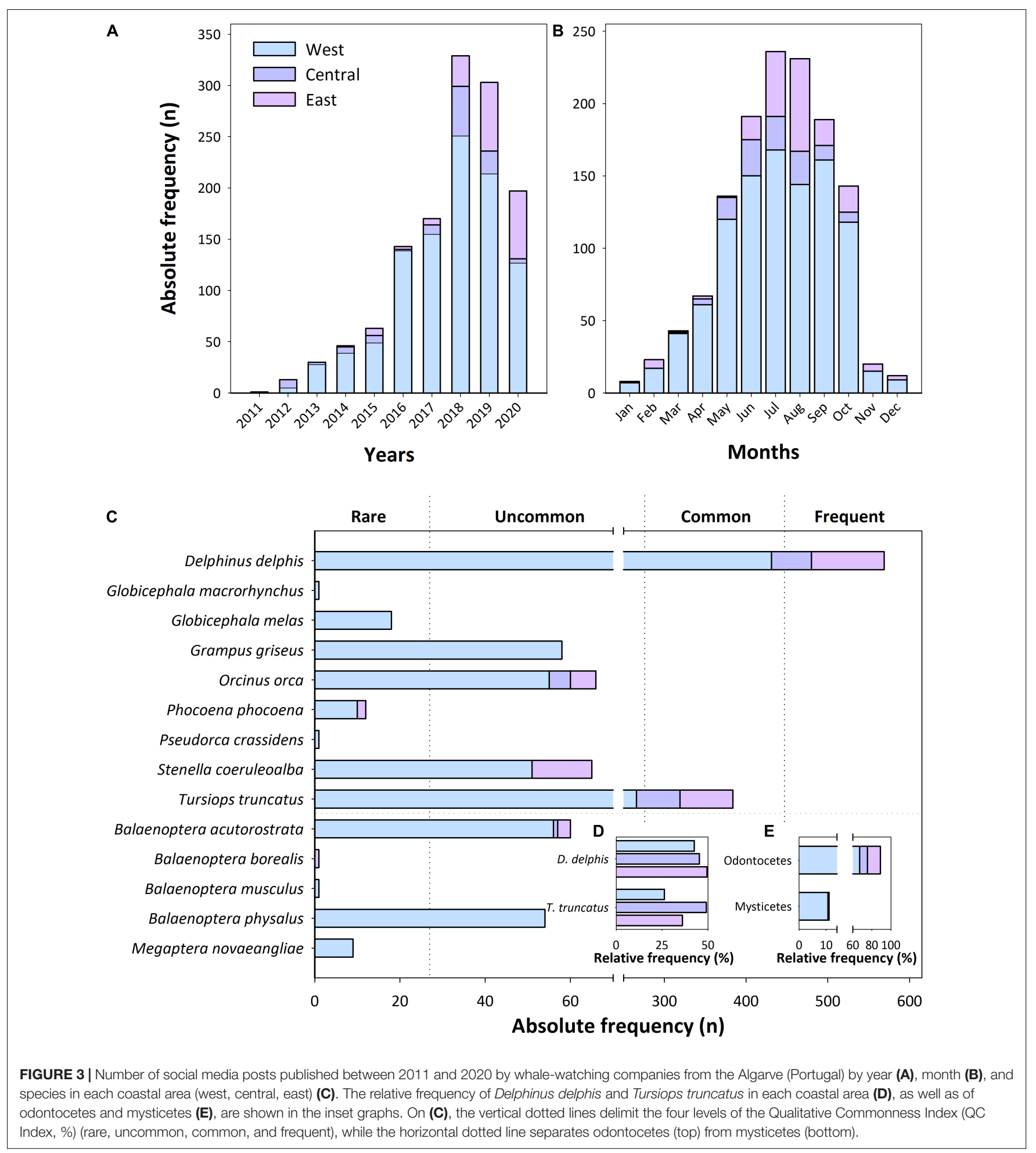

the number of species to have ever been observed in the region to 24 (Table 2). The record of Balaenoptera edeni in 2021beyond the 10-year scope of our study-shows the importance of continuously monitoring social media in such a poorly monitored region. The three most comprehensive studies made about the abundance and distribution of cetaceans in the Algarve are only published as gray literature and registered fewer species. One study registered the presence of six species between Sagres and Lagos during a little over 8 months (February 14-October 26, 2009; 412 h; 9599 km)-Balaenoptera acutorostrata, Delphinus 


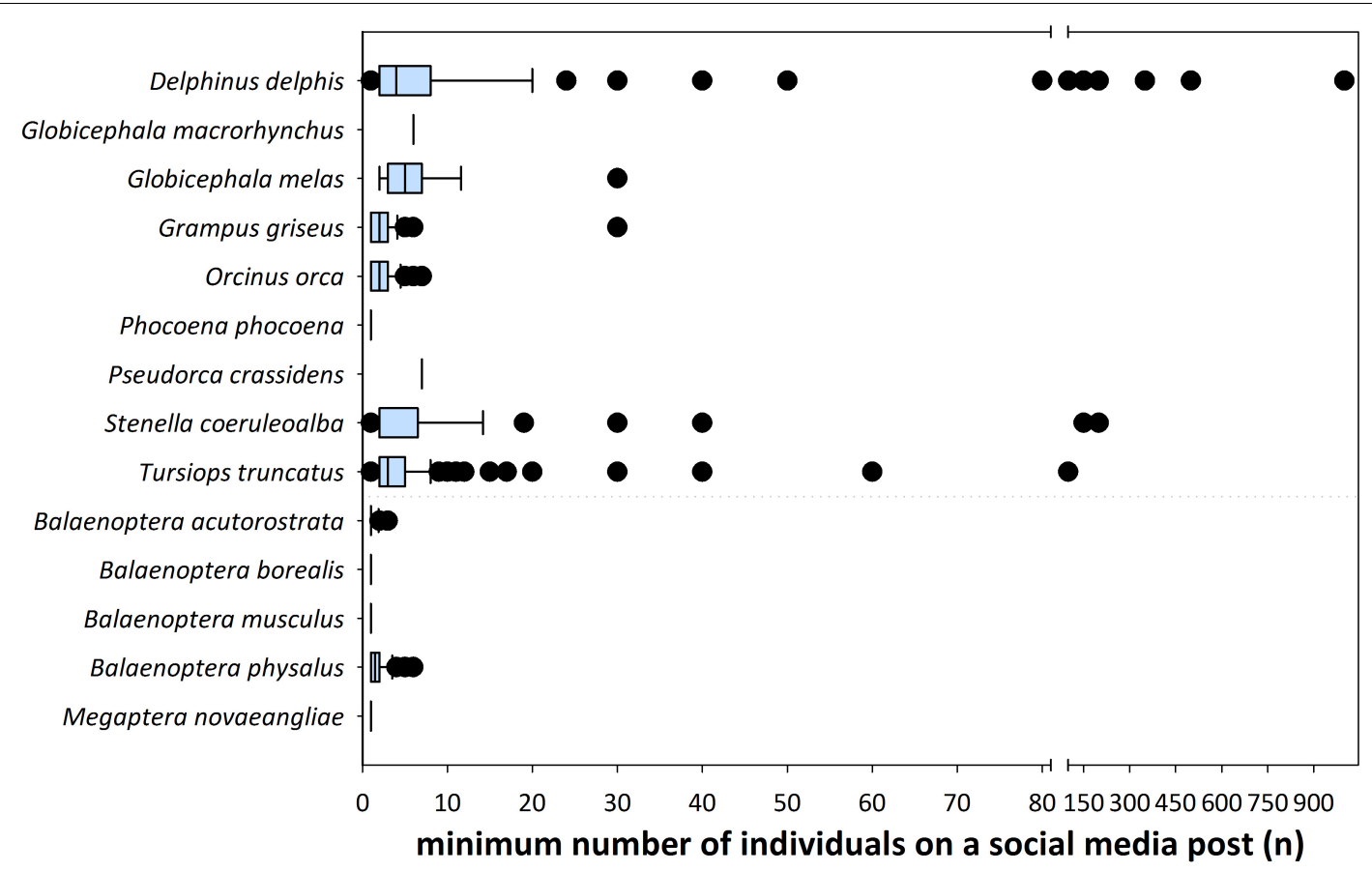

FIGURE 4 | Median, standard error, 25th and 75th percentiles, and outliers of the minimum number of individuals registered in each record and for each cetacean species shown on social media posts published between 2011 and 2020 in the Facebook and Instagram accounts of whale-watching companies from the Algarve (Portugal). The horizontal dotted line separates odontocetes (top) from mysticetes (bottom).

delphis, Grampus griseus, Megaptera novaeangliae, Phocoena phocoena, Tursiops truncatus (Castro, 2010). A second study covered the entire region and reported 11 species (Balaenoptera acutorostrata, Balaenoptera borealis, Balaenoptera physalus, Delphinus delphis, Globicephala melas, Grampus griseus, Megaptera novaeangliae, Orcinus orca, Phocoena phocoena, Stenella coeruleoalba, Tursiops truncatus) between May and October of 2010, until 2019 (Laborde et al., 2019).

Despite that seven species were reported for the Algarve and are missing from the list of species recorded by whale-watching companies on social media (Table 2), these species are extremely rare. Six species have only been mentioned in the gray literature, refer exclusively to stranded individuals, and concerning records made between 1978 and 2017 (Kogia breviceps- 3 individuals, Kogia simus- 2 individuals, Mesoplodon bidens- 1 individual, Mesoplodon europaeus- 1 individual, Mesoplodon mirus- 5 individuals, Ziphius cavirostris- 2 individuals) (Sabino-Marques, 2005; Carvalho, 2018; Carvalho et al., 2019, Table 2). The other species, Eubalaena glacialis, was only mentioned in one peerreviewed publication describing the sighting of one adult and a calf which made from land in February 1995 (Martin and Walker, 1997). Although the record of Physeter macrocephalus reported in our study was not time-referenced, we decided to keep it in the list of species registered by whale-watching companies because there is only one reference about this species in peerreviewed articles mentioning a mass stranding of 10 individuals in 1784 in Olhos de Água (4 km to the east of Albufeira) (Sousa and Brito, 2012).
In the Algarve, the citizen science biodiversity platform (Biodiversity4All) did not complement the records from social media (Facebook and Instagram), yet its greatest advantage is that provides georeferenced records. The number of records on Biodiversity4All (82 records) was 15.8 times lower than social media posts (1299 posts) and only gathered information of nine species, but both datasets revealed the same trend in terms of proportions between odontocetes and mysticetes. The use of online biodiversity platforms should not be abandoned because its relevance is uneven around the world (iNaturalist, 2021) and increases if a citizen science project requests the upload of records into a platform (Encarnação et al., 2021b; Rodriguez et al., 2021). So, the solution is to continue promoting citizen science as a whole and incentivize people to share their sightings about cetaceans on online biodiversity platforms. Despite the few records made in the Algarve and available on Biodiversity4All, these could still improve the information shown on the Atlas of marine mammals in Portugal (Moura et al., 2019), including for the most common species (Delphinus delphis, Tursiops truncatus) or if records overlap with existing locations (Grampus griseus). This is so because continued monitoring of occurrence and abundance is an important component of management and conservation, and these platforms provide a unique opportunity for this information to continue to be collected, especially given that the government or other organizations are unlikely to be able to conduct periodic monitoring surveys. For the other seven species, Biodiversity4All would provide the first record of a species in the Atlas for the Algarve (Balaenoptera physalus) or 


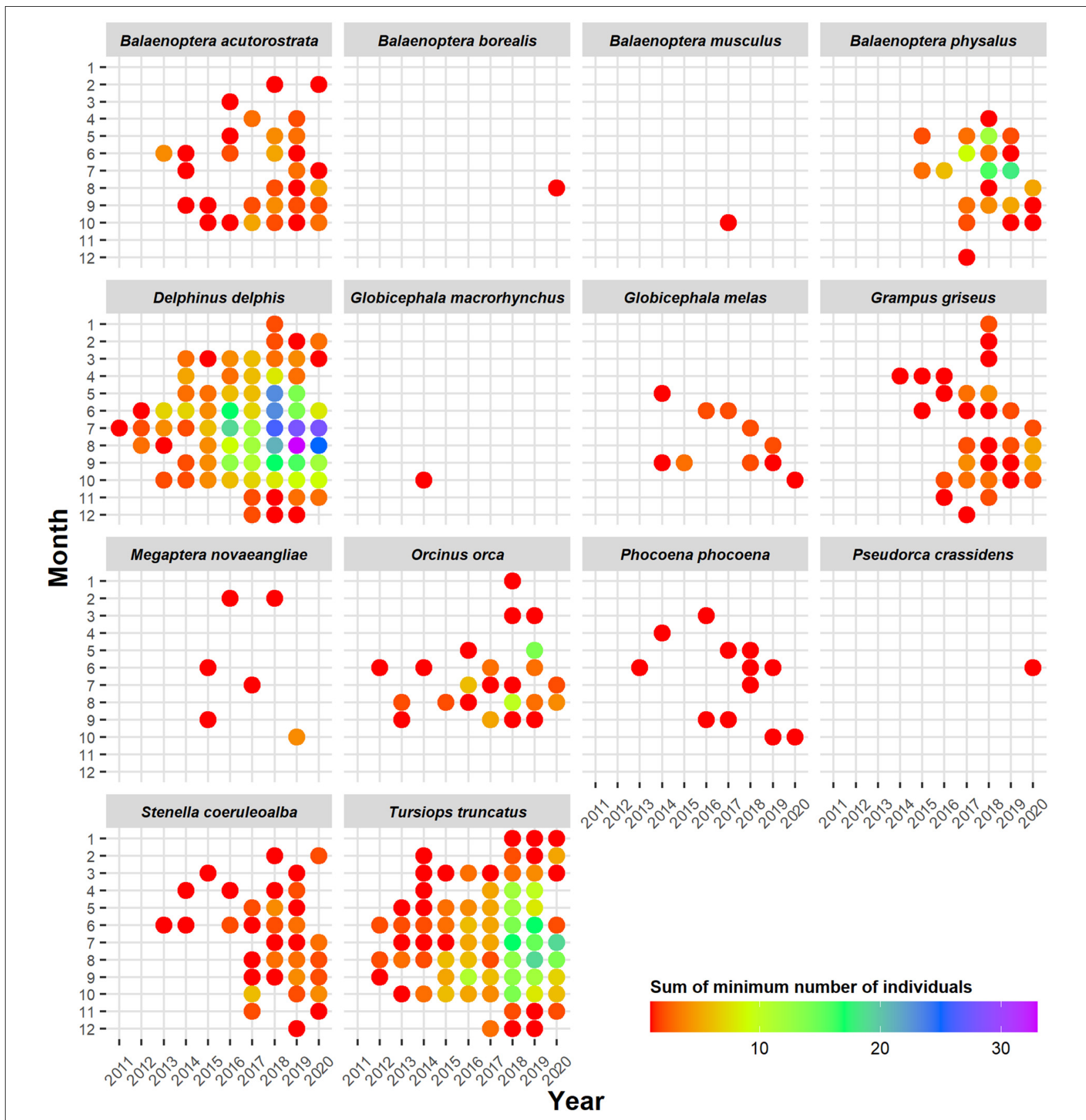

FIGURE 5 | Monthly sum of the minimum number of individuals of each cetacean species shown on social media posts published between 2011 and 2020 in the Facebook and Instagram accounts of whale-watching companies from the Algarve (Portugal).

would increase the low number of records in the Algarve, which vary from four records for Balaenoptera physalus and Stenella coeruleoalba to nine records for Balaenoptera acutorostrata.

The whale-watching industry is highly seasonal, so it was unsurprising that $86.7 \%$ of records made on social media were made during 6 months-between May and October. Despite the industry's seasonality, some companies operate year-round, so we gathered records made every single month of the year in the 2 years before the COVID-19 pandemic $(2018,2019)$. Most species were observed in every season except for the rarest species-Balaenoptera borealis, Balaenoptera musculus, Megaptera novaeangliae, and Pseudorca crassidens (see Figure 5 


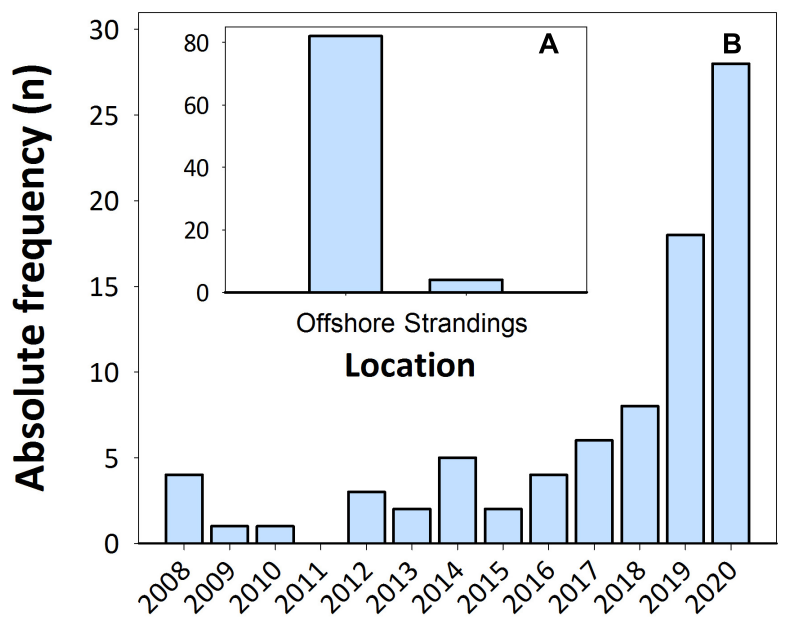

Years

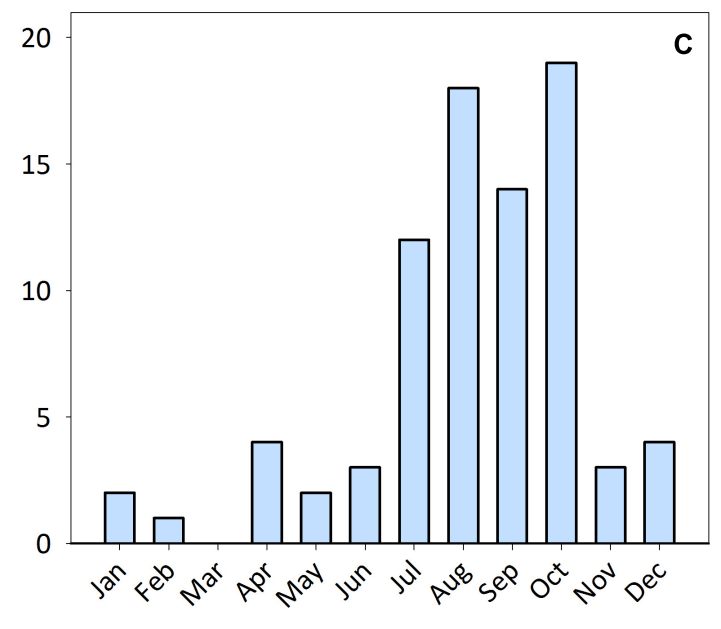

Months

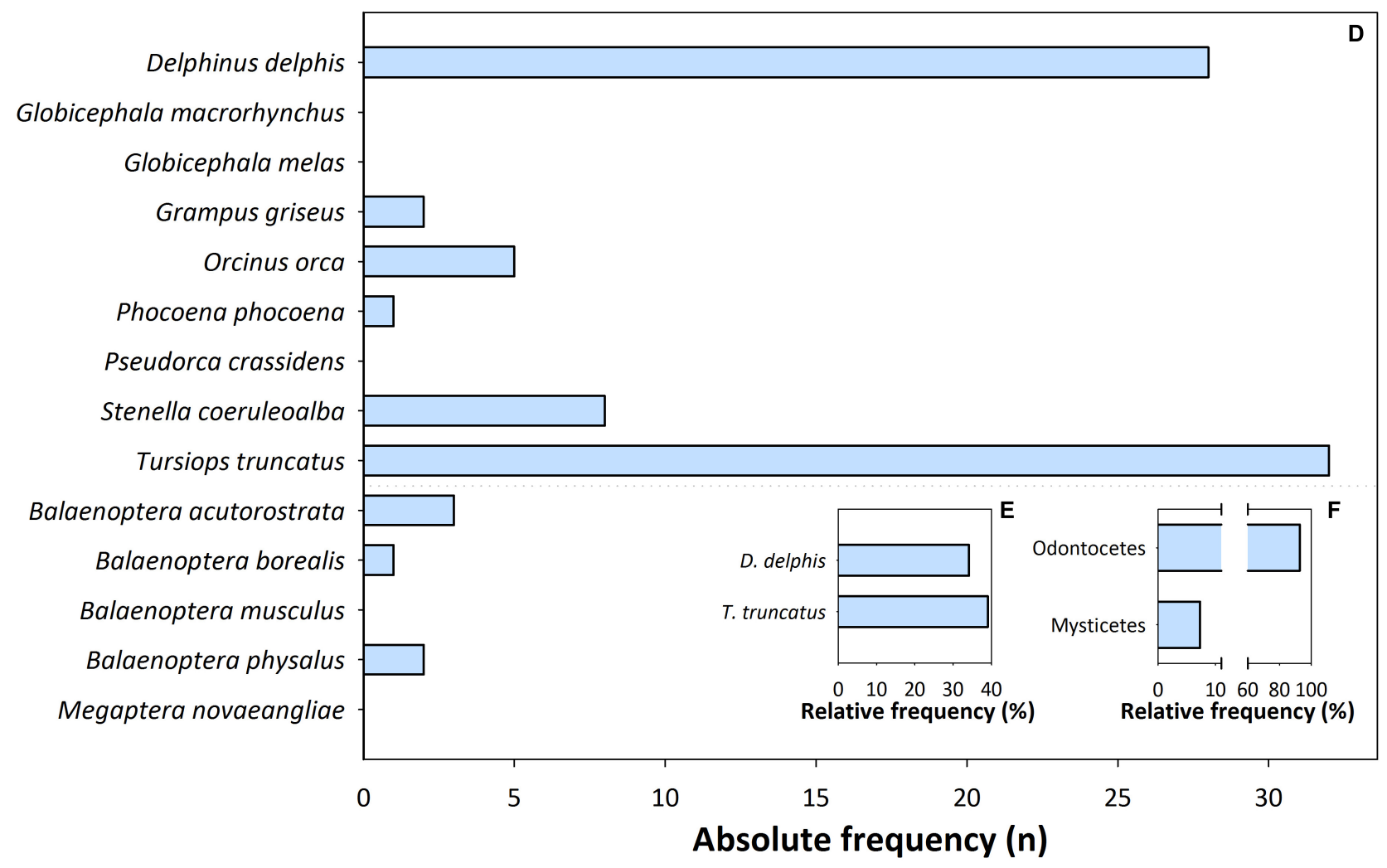

FIGURE 6 | Number of records of cetaceans observed offshore or stranded in the Algarve (Portugal) (A) published between 2008 and 2020 on Biodiversity4All, as well as the total number of records made in each year (B), month (C), and of each species (D). The relative frequency of Delphinus delphis and Tursiops truncatus in the Algarve (E), as well as of odontocetes and mysticetes (F), are shown in the inset graphs.

for details). The identification of seasonality patterns of presence or abundance is still impossible to disentangle because the observation effort is unknown. Because of this, one of the major concerns about iEcology is the over-representation of emblematic or rare species. This can certainly be the case with cetaceans since rare dolphins or whales attract more attention and clients for whale-watching companies. Although we cannot evaluate this aspect with accuracy, we estimate that odontocetes are slightly underrepresented in our study. A field study with a total effort of $3,768 \mathrm{~h}$, made onboard the boats of whale-watching companies off the Algarve, registered $97.0 \%$ of odontocetes (May-October 2010, 2011, 2012) (Castro et al., 2013b), while they represent 
A

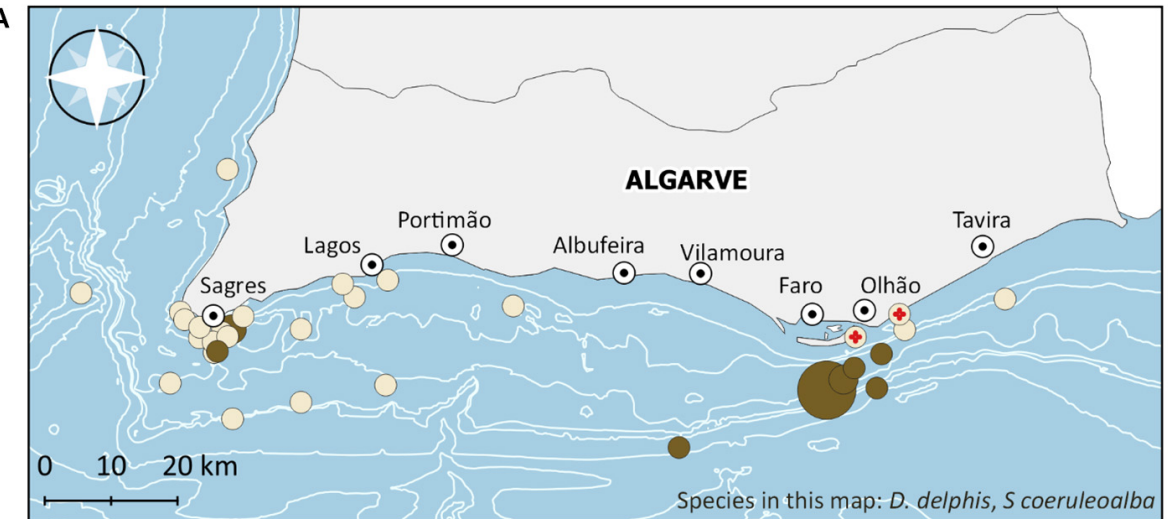

B

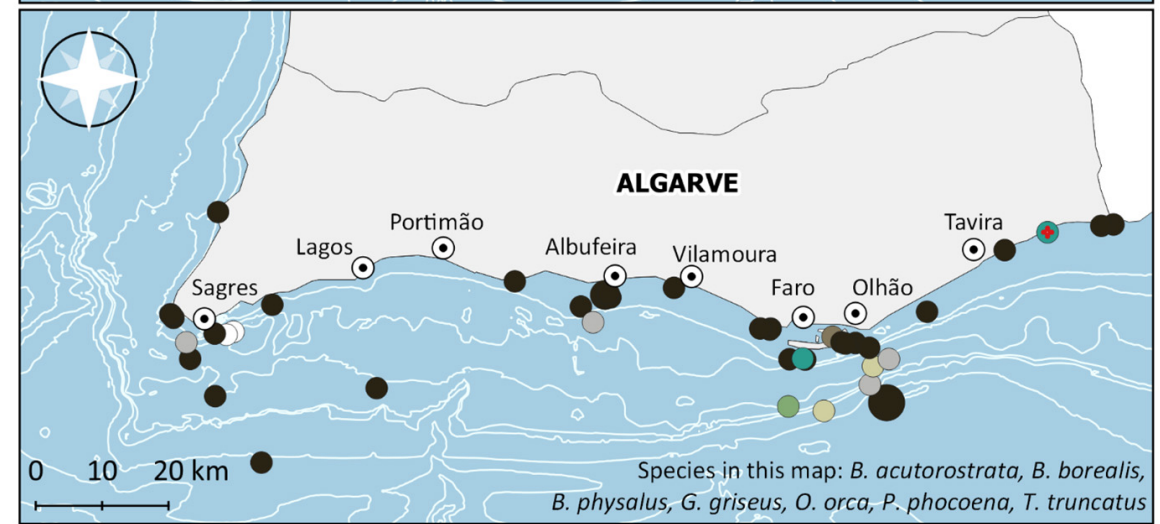

Species

Balaenoptera acutorostrata

Balaenoptera borealis

Balaenoptera physalus

Delphinus delphis

Grampus griseus

Orcinus orca

Phocoena phocoena

Stenella coeruleoalba

Tursiops truncatus

Minimum number of individuals

\begin{tabular}{l}
$1-7$ \\
$8-14$ \\
150 \\
400 \\
1000 \\
1500 \\
$+\quad$ dead individuals found ashore \\
\hline
\end{tabular}

FIGURE 7 | Location and the minimum number of individuals of nine cetacean species recorded on Biodiversity4All between 2008 and 2020 , including dead individuals found ashore. Records are displayed in two panels to avoid the superposition of observations: (A) Delphinus delphis, Stenella coeruleoalba; (B) Balaenoptera acutorostrata, Balaenoptera borealis, Balaenoptera physalus, Grampus griseus, Orcinus orca, Phocoena phocoena, Tursiops truncatus. Two records out of the 82 valid records obtained from Biodiversity4All were not included in this map because the coordinates placed the observations inland (Delphinus delphis on October 6, 2016, off Sagres; Orcinus orca on August 17, 2019, off Faro). Bathymetry data provided by General Bathymetric Chart of the Oceans (www.GEBCO.net).

$90.4 \%$ of the records on social media. Whales are indeed far rarer off the Algarve, so any sighting of mysticetes is more likely to be announced on social media.

Despite the caveats (unknown observation effort, putative misrepresentation of rare species, low spatial resolution), this study clearly showed how useful the social media of whalewatching companies can become to reveal the diversity of cetaceans in touristic areas. We obtained the longest time series of occurrences so far in the Algarve. In coming years, with more and more frequent reports in social media posted by whale watching companies, as already shown in 2018 and 2019 (before the COVID-19 pandemic), progress in social media data-mining, and increased awareness about citizen science, it may be possible to extract long-term trends or changes in abundance as crude indicators of ecological trends.

\section{Advantages and Disadvantages of iEcology to Study Cetaceans}

The use of generalist social media can play an important role in conservation science if the research questions and interpretation of data acknowledge the limitations of this approach (Aravind, 2013; Di Minin et al., 2015). In the case of the Algarve, data from a biodiversity platform did not enrich the information already obtained with the social media platforms. This is likely to be different in other regions of the world where both data sources add significant value to the general dataset, or that social media is far less relevant.

This work revealed that the greatest advantages of iEcology to study cetaceans is the possibility to obtain numerous records made throughout a long period [1381 records -1299 records on Facebook and Instagram since 2011, and 82 records on Biodiversity4All since 2008] and even georeferenced [only with Biodiversity4All], besides its low cost. We identified three disadvantages. First, it is impossible to obtain the precise location where the observations reported on Facebook and Instagram were made-although this can be minimized since whalewatching companies operate along a restricted stretch of the coast (up to 10 miles from the coast) and in the vicinity of the port where they are based. Currently, EXIF data (Exchangeable Image File Format) is removed from photos posted on Facebook and Instagram before they are published so it is impossible to obtain georeferenced information if that was included in the photograph. Second, it is difficult to estimate the number of individuals of large groups of dolphins-mainly Delphinus delphis and Tursiops truncatus off the Algarve. In this region, 
TABLE 2 | List of the 24 cetacean species that have ever been registered in the Algarve.

\begin{tabular}{|c|c|c|c|c|}
\hline Cetaceans of the Algarve & Conservation status & This study & Peer reviewed & Gray literature \\
\hline Balaenoptera acutorostrata Lacépède, 1804 Common minke whale & $\mathrm{LC}^{1,2}$ & $\checkmark$ & Q & $\mathrm{D}, \mathrm{E}, \mathrm{F}, \mathrm{G}, \mathrm{I}, \mathrm{T}, \mathrm{U}$ \\
\hline Balaenoptera borealis Lesson, 1828 Sei whale & $\mathrm{EN}^{1,2}$ & $\checkmark$ & - & $\mathrm{F}, \mathrm{I}, \mathrm{T}, \mathrm{U}$ \\
\hline Balaenoptera edeni Olsen, 1913 Bryde's whale & $\mathrm{LC}^{1}$ & $\checkmark$ & - & - \\
\hline Balaenoptera musculus Linnaeus, 1758 Blue whale & $\mathrm{EN}^{1,2}$ & $\checkmark$ & - & - \\
\hline Balaenoptera physalus Linnaeus, 1758 Fin whale & $\mathrm{VU} \mathrm{U}^{1,3} / \mathrm{NT}^{2}$ & $\checkmark$ & $\mathrm{AF}$ & $F, I, S, U, A E$ \\
\hline Delphinus delphis Linnaeus, 1758 Short-beaked common dolphin & $\mathrm{LC}^{1} / \mathrm{DD}^{2} / \mathrm{EN}^{3}$ & $\checkmark$ & $J, K, Q, Y, Z, A C, A G$ & $E, F, G, H, I, O, S, U, A F$ \\
\hline Eubalaena glacialis Müller, 1776 North Atlantic right whale & $\mathrm{CR}^{1,2}$ & - & $\mathrm{AB}$ & - \\
\hline Globicephala macrorhynchus Gray, 1846 Short-finned pilot whale & $L C^{1}$ & $\checkmark$ & B & - \\
\hline Globicephala melas Traill, 1809 Long-finned pilot whale & $\mathrm{LC}^{1} / \mathrm{DD}^{3}$ & $\checkmark$ & Q & $\mathrm{F}, \mathrm{U}, \mathrm{AF}$ \\
\hline Grampus griseus G. Cuvier, 1812 Risso's dolphin & $\mathrm{LC}^{1 / 1} \mathrm{DD}^{2,3}$ & $\checkmark$ & Q & $E, F, G, I, R, U, A D, A F, A l$ \\
\hline Kogia breviceps de Blainville, 1838 Pygmy sperm whale & DD & - & - & $E, A F$ \\
\hline Kogia sima Owen, 1866 Dwarf sperm whale & $\mathrm{LC}^{1} / \mathrm{NA}^{2}$ & - & - & $E, A F$ \\
\hline Megaptera novaeangliae Borowski, 1781 Humpback whale & $\mathrm{LC}^{1,2}$ & $\checkmark$ & - & $E, G, T, U$ \\
\hline Mesoplodon bidens Sowerby, 1804 Sowerby's beaked whale & $\mathrm{LC}^{1} / \mathrm{DD}^{2}$ & - & - & $\mathrm{F}$ \\
\hline Mesoplodon europaeus Gervais, 1855 Gervais' beaked whale & $\mathrm{LC}^{1} / \mathrm{DD}^{2}$ & - & - & $E$ \\
\hline Mesoplodon mirus True, 1913 True's beaked whale & $\mathrm{LC}^{1} / \mathrm{DD}^{2}$ & - & - & $E, F$ \\
\hline Mesoplodon spp. beaked whale & - & - & - & $\mathrm{F}, \mathrm{AF}$ \\
\hline Orcinus orca Linnaeus, 1758 Killer whale & $\mathrm{DD}^{1,2} / \mathrm{CR}^{4}$ & $\checkmark$ & $N, Q$ & $U, A E$ \\
\hline Phocoena phocoena Owen, 1846 Harbour porpoise & $\mathrm{LC}^{1} N \mathrm{NU}^{2}$ & $\checkmark$ & Q & $C, E, F, G, I, U, A F$ \\
\hline Physeter macrocephalus Linnaeus, 1758 Sperm whale & $V U^{1,2} / E N^{3}$ & $\checkmark$ & $\mathrm{Q}, \mathrm{AH}$ & $\mathrm{B}, \mathrm{C}, \mathrm{V}$ \\
\hline Pseudorca crassidens Owen, 1846 False killer whale & $N T^{1} / \mathrm{NA}^{2}$ & $\checkmark$ & - & $E, F, A F$ \\
\hline Stenella coeruleoalba Meyen, 1833 Striped dolphin & $\mathrm{LC}^{1} / \mathrm{DD}^{2} \mathrm{NU^{3 }}$ & $\checkmark$ & $\mathrm{Q}, \mathrm{AA}$ & $E, F, U, A F$ \\
\hline Tursiops truncatus Montagu, 1821 Common bottlenose dolphin & $L C^{1} N U^{3}$ & $\checkmark$ & $\mathrm{K}, \mathrm{M}, \mathrm{P}, \mathrm{Q}$ & $A, E, F, G, I, L, U, V, W, X, A F, A_{\iota}$ \\
\hline Ziphius cavirostris Cuvier, 1823 Cuvier's beaked whale & $\mathrm{LC}^{1} / \mathrm{DD}^{2,3}$ & - & - & $E, F, A F$ \\
\hline
\end{tabular}

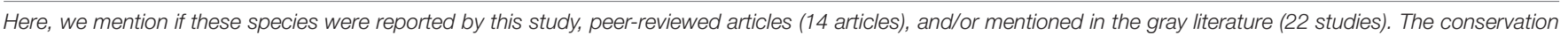

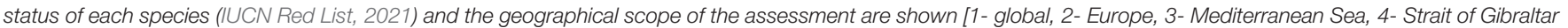

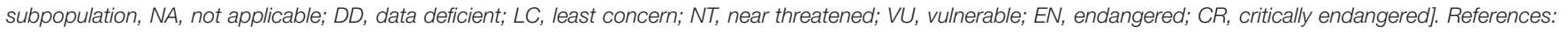

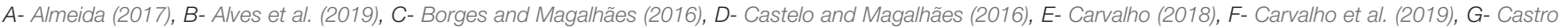

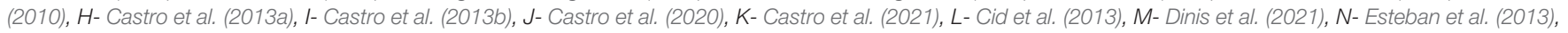

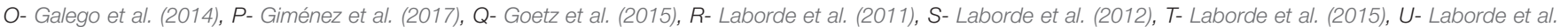

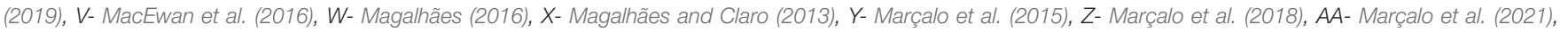

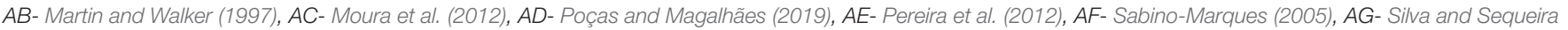
(2003), AH-Sousa and Brito (2012), Al- Stekke et al. (2011), AJ-Vieira (2017).

groups of Delphinus delphis, including newborns and calves, can reach up to 1,000 individuals and averaging $31.0 \pm 51.6$ individuals (Moura et al., 2012; Castro et al., 2020), however, the average of the minimum number of individuals we retrieved from social media was two times lower-14.1 \pm 53.5 individuals. This is less problematic for most species because they were present in small groups, or the posts often mentioned the number of individuals observed. The third disadvantage concerns rare or uncommon species because multiple whale-watching companies along the coast can post photographs/videos of the same individual(s), therefore artificially inflating the presence of the species in a given region.

Overall, when taking into consideration the advantages of iEcology and if the disadvantages are carefully assessed and disclosed, social media posts from whale-watching companies can reveal critical information about cetaceans in poorly monitored regions of the world. Eventually, iEcology data from these regions can lead to the proposal and implementation of conservation plans (Pace et al., 2019) and other studies (e.g., photo-identification) (Gibson et al., 2020), or more importantly, providing valuable information for the inventory of the global conservation status of cetaceans by the International Union for Conservation of Nature (IUCN).

\section{Developing the Cetacean Observation Log as a Conservation Tool}

Social media can complement and, in some situations, compensate for the lack of field studies (Toivonen et al., 2019; Jarić et al., 2020; Al Mabruk et al., 2021), particularly when the goal is to record the absence/presence of species. However, social media data may be very volatile and ephemerous because a social media platform may close, an account can be eliminated if a whale-watching company closes, or relevant posts for ecologists can be deleted at the company's discretion. This weakness could be partially alleviated if whale-watching companies also posted their daily encounters on their websites (e.g., Monterey Whale Watching-montereywhalewatching.com/category/daily sightings) or by making their data available for the scientific community on more robust platforms or data repositories.

We have shown that the social media of whale-watching companies from the Algarve provided quality information 
that cannot be neglected by cetacean scientists, NGOs, and national and international environmental agencies. Several whale-watching companies have already contributed to many scientific studies and play a determinant educational role, however, there are unexplored opportunities for environmental agencies and academia to collaborate with them and obtain standardized data. We are convinced that whale-watching companies would likely be willing to contribute with more detailed information if that would be requested by national environmental agencies. We propose the creation of an official standardized cetacean observation log for whale-watching companies to register the observations made in each trip, the equivalent-in concept-to the information that fishing boats need to register about their fishing activities. The cetacean observation log could be uploaded on a public biodiversity database-once validated-to provide timely information to scientists, NGOs, and environmental agencies similarly to national official fishing stats. The information that could be included in the log of each trip would be the length of each trip, coordinates of where each species was observed, time, number (or estimate) of individuals observed, presence/absence of newborns or calves and how many, behavior (e.g., traveling, preying, playing, type of interaction with other species), the direction of swimming (i.e., to the east, west, south, north), and conditions of the sea and wind (Beaufort wind force scale, Douglas sea scale). The Algarve has shown to be the ideal region to test the applicability of a standardized cetacean observation log as a source of information for conservation policies which could then be adopted by other countries in the European Union and around the world.

\section{CONCLUSION}

The social media posts of whale-watching companies located in the Algarve were essential to obtain the first broadscale and long-term assessment of cetaceans' diversity off the Algarve. Social media platforms (Facebook, Instagram) provided substantially more information than a citizen science biodiversity platform (Biodiversity4All), and data from the latter did not complement the information already retrieved from social media. However, this reflects the particular context of where this study was made and not a pattern that is mirrored in other regions of the world. The main advantage of iEcology to study the cetaceans off the Algarve was the possibility to obtain data collected over one decade, besides its low cost. The main disadvantages of data retrieved from social media are the impossibility to obtain a precise location where the observations were made, difficulty to estimate the number of individuals of large groups of individuals, and the likelihood of inflating the presence of rare species if multiple whale-watching companies post photographs/videos of the same individual(s) while they migrate along the coast. Nonetheless, these disadvantages can be mitigated. Overall,
iEcology can be useful to increase the ecological knowledge about cetaceans in regions of the world where scientific data is scarce or inexistent. The creation and implementation of a cetacean observation log filled by whale-watching companies would provide critical information for conservation policies. So, scientists and environmental agencies should proactively pursue collaborations with whale-watching companies to implement this strategy around the world.

\section{DATA AVAILABILITY STATEMENT}

The datasets presented in this article will be made available upon request and full disclosure of its use. Reuse of data and incorporation into other datasets is possible upon agreement. Requests to access the datasets should be directed to the corresponding author.

\section{ETHICS STATEMENT}

Ethical review and approval was not required for the animal study because this study obtained data from social media posts (Facebook, Instagram) published by whale watching companies and others available on Biodiversity4All, a citizen science biodiversity database.

\section{AUTHOR CONTRIBUTIONS}

PM conceptualized the study, obtained the funding, coordinated data collection, revised the data, analyzed the data, and wrote the article. LA collected the data and revised the article. ED conceptualized the study, obtained the funding, and revised the article. All authors contributed to the article and approved the submitted version.

\section{FUNDING}

LA received a scholarship funded by the Blue Young Talent program sponsored by CIIMAR (Interdisciplinary Centre of Marine and Environmental Research, University of Porto, Portugal). This research received funds granted by Foundation for Science and Technology (FCT, Portugal) to CCMAR (UIDB/04326/2020) and CIIMAR (UIDB/04423/2020 and UIDP/04423/2020).

\section{ACKNOWLEDGMENTS}

We acknowledge J. Higham, Daniel Palacios, and Filipe Alves for their suggestions which helped to improve the initial version of this article. This is contribution number 1364 from the Institute of Environment at Florida International University. 


\section{REFERENCES}

Aichner, T., Grünfelder, M., Maurer, O., and Jegeni, D. (2021). Twenty-five years of social media: a review of social media applications and definitions from 1994 to 2019. Cyberpsychol. Behav. Soc. Netw. 24, 215-222. doi: 10.1089/cyber.2020. 0134

Al Mabruk, S. A. A., Abdulghani, A., Nour, O. M., Adel, M., Crocetta, F., Doumpas, N., et al. (2021). The role of social media in compensating for the lack of field studies: five new fish species for the Mediterranean Egypt. J. Fish Biol. 99, 673-678. doi: 10.1111/jfb.14721

Almeida, D. (2017). Distribution and Habitat Use of Bottlenose Dolphin (Tursiops truncatus) in Central and South West of Portugal Mainland. M.Sc dissertation. Lisbon: University of Lisbon.

Alves, F., Alessandrini, A., Servidio, A., Mendonça, A. S., Hartman, K. L., Prieto, R., et al. (2019). Complex biogeographical patterns support an ecological connectivity network of a large marine predator in the north-east Atlantic. Divers. Distrib. 25, 269-284. doi: 10.1111/ddi. 12848

Alves, F., Ferreira, R., Fernandes, M., Halicka, Z., Dias, L., and Dinis, A. (2018). Analysis of occurrence patterns and biological factors of cetaceans based on long-term and fine-scale data from platforms of opportunity: madeira Island as a case study. Mar. Ecol. 39:e12499. doi: 10.1111/maec.12499

Aravind, N. A. (2013). Potential of social network and internet media in biodiversity mapping and conservation. Curr. Sci. 105, 291-293.

Azzurro, E., and Tiralongo, F. (2020). First record of the mottled spinefoot Siganus fuscescens (Houttuyn, 1782) in Mediterranean waters: a Facebook based detection. Mediterr. Mar. Sci. 21, 448-451.

Báez, J., Camiñas, J., and Torreblanca, D. (2007). Analysis of spatial distribution for the marine bird and mammal in the Gulf of Cadiz (South-west of the Iberian Peninsula) during spring period. Bol. R. Soc. Esp. Hist. Nat. Sec. Biol. 102, 93-97.

Bento, M., Eira, C., Vingada, J. V., Marçalo, A. L., Ferreira, M., Fernandez, A. L., et al. (2016). New insight into dolphin morbillivirus phylogeny and epidemiology in the northeast Atlantic: opportunistic study in cetaceans stranded along the Portuguese and Galician coasts. BMC Vet. Res. 12:176. doi: 10.1186/s12917-016-0795-4

Biodiversity4All (2021). Biodiversity4All. Available online at: www.Biodiversity4All.org (accessed March 19, 2021).

Borges, A. S., and Magalhães, S. (2016). "Spatial and temporal variation of harbour porpoise (Phocoena phocoena) in south western coast of Portugal," in Proceedings of the 30th Conference of the European Cetacean Society, Into the Deep: Research and Conservation on Oceanic Marine Mammals, eds L. Freitas, and C. Ribeiro (Machico), 219.

Carvalho, F. (2018). Arrojamentos de Cetáceos ao Longo da Costa do Algarve: Causas de Morte e Ensaios Piloto de Mitigação com Alarmes Acústicos em Pescarias Costeiras Algarvias. M.Sc dissertation. Faro: University of Algarve.

Carvalho, F., Marçalo, A., Casero, M., Sequeira, M., Vingada, J., and Nicolau, L. (2019). "Spatio-temporal characterization of cetacean strandings and main causes of mortality along western southern Iberia, 1978-2017," in Proceedings of the World Marine Mammal Conference 2019, eds M. Gazo, C. A. Chicote, A. Pabst, and M. Aqcuarone, Barcelona, 81.

Castro, J. (2010). Characterization of Cetaceans in the South Coast of Portugal Between Lagos and Cape São Vicente. M.Sc dissertation. Lisbon: University of Lisbon.

Castelo, D., and Magalhães, S. M. (2016). "Minke whale (Balaenoptera acutorostrata) occurrence and distribution in Southwestern Portugal," in Proceedings of the 30th Conference of the European Cetacean Society, Into the Deep: Research and Conservation on Oceanic Marine Mammals, eds L. Freitas, and C. Ribeiro (Machico), 257.

Castro, J., Borges, F. O., Cid, A., Laborde, M. I., Rosa, R., and Pearson, H. C. (2021). Assessing the behavioural responses of small cetaceans to unmanned aerial vehicles. Remote Sens. 13:156. doi: 10.3390/rs13010156

Castro, J., Cid, A., Fonseca, C., Galego, S., and Laborde, M. (2013b). "Cetacean monitoring in the South Coast of mainland Portugal," in Proceedings of the 20th Biennial Conference on the Biology of Marine Mammal, Dunedin, eds E. Slooten, T. Webster, S. Dawson, W. Rayment, C. L. S. da Silva, B. Robertson, et al. (Dunedin: Society for Marine Mammalogy), 38.

Castro, J., Cid, A., Fonseca, C., Galego, S., and Laborde, M. (2013a). "Algarve region as a potential breeding ground for common dolphins in Portugal," in Proceedings of the 27th Conference of the European Cetacean Society, Interdisciplinary Approaches in the Study of Marine Mammals, eds M. Sequeira, C. Brito, I. Carvalho, C. Picanço, R. Amaral, T. Marques, et al. (Setúbal), 259.
Castro, J., Couto, A., Borges, F. O., Cid, A., Laborde, M. I., Pearson, H. C., et al. (2020). Oceanographic determinants of the abundance of common dolphins (Delphinus delphis) in the South of Portugal. Oceans 1, 165-173. doi: 10.3390/ oceans 1030012

Cid, A., Marina, M. I., Fonseca, C., Galego, S., and Castro, J. (2013). "The bottlenose dolphin (Tursiops truncatus) in Southern Portugal (Southwestern Europe)," in Proceedings of the 20th Biennial Conference on the Biology of Marine Mammals, Dunedin, eds E. Slooten, T. Webster, S. Dawson, W. Rayment, C. L. S. da Silva, B. Robertson, et al. (Dunedin: Society for Marine Mammalogy), 44-45.

Claro, B. (2009). Caracterização Sócio-Económica do Turista de Observação Turística de Cetáceos no Algarve e Determinação do Seu Grau de Satisfação e Perfil Ecológico. M.Sc dissertation. Faro: University of Algarve.

Correia, A. M., Sousa-Guedes, D., Gil, Á, Valente, R., Rosso, M., Sousa-Pinto, I., et al. (2021). Predicting cetacean distributions in the Eastern North Atlantic to support marine management. Front. Mar. Sci. 8:643569. doi: 10.3389/fmars. 2021.643569

Daume, S. (2016). Mining Twitter to monitor invasive alien species - An analytical framework and sample information topologies. Ecol. Inform. 31, 70-82. doi: 10.1016/j.ecoinf.2015.11.014

Di Minin, E., Tenkanen, H., and Toivonen, T. (2015). Prospects and challenges for social media data in conservation science. Front. Environ. Sci. 3:63. doi: 10.3389/fenvs.2015.00063

Dinis, A., Molina, C., Tobeña, M., Sambolino, A., Hartman, K., Fernandez, M., et al. (2021). Large-scale movements of common bottlenose dolphins in the Atlantic: dolphins with an international courtyard. PeerJ 9:e11069. doi: 10.7717/peerj. 11069

Encarnação, J., Baptista, V., Teodósio, M. A., and Morais, P. (2021a) Low-cost citizen science effectively monitors the rapid expansion of a marine invasive species. Front. Environ. Sci. 9:752705. doi: 10.3389/fenvs.2021.752705

Encarnação, J., Teodósio, M. A., and Morais, P. (2021b). Citizen science and biological invasions: a review. Front. Environ. Sci. 8:602980. doi: 10.3389/fenvs. 2020.602980

Esteban, R., Verborgh, P., Gauffier, P., Giménez, J., Afán, I., Cañadas, A., et al. (2013). Identifying key habitat and seasonal patterns of a critically endangered population of killer whales. J. Mar. Biol. Assoc. U. K. 94, 1317-1325. doi: 10. 1017/S002531541300091X

Evans, P., and Hammond, P. (2004). Monitoring cetaceans in European waters. Mamm. Rev. 34, 131-156. doi: 10.1046/j.0305-1838.2003.00027.x

Galego, S., Castro, J., and Laborde, M. I. (2014). "Potential effects of whale watching on common dolphins in the South coast of mainland Portugal," in Proceedings of the 28th Conference of the European Cetacean Society, Marine Mammals as Sentinels of a Changing Environment, Liège, eds K. Das, T. Jauniaux, R. Blust, J.-M. Bouquegneau, F. Coignoul, A. Covaci, et al. (Liége: European Cetacean Society), 152.

Gibson, C. E., Williams, D., Dunlop, R., and Beck, S. (2020). Using social media as a cost-effective resource in the photo-identification of a coastal bottlenose dolphin community. Aquat. Conserv. 30, 1702-1710. doi: 10.1002/aqc.3356

Giménez, J., Marçalo, A., Ramirez, F., Verborgh, P., Gauffier, P., Esteban, R., et al. (2017). Diet of bottlenose dolphins (Tursiops truncatus) from the Gulf of Cadiz: insights from stomach content and stable isotope analyses. PLoS One 12:e0184673. doi: 10.1371/journal.pone.0184673

Goetz, S., Read, F. L., Ferreira, M., Portela, J. M., Santos, M. B., Vingada, J., et al. (2015). Cetacean occurrence, habitat preferences and potential for cetaceanfishery interactions in Iberian Atlantic waters: results from cooperative research involving local stakeholders. Aquat. Conserv. 25, 138-154. doi: 10.1002/aqc. 2481

Governo de Portugal (2006). Diário da República n. ${ }^{\circ}$ 5/2006, Série I-A de 200601-06. Available online at: https://data.dre.pt/eli/dec-lei/9/2006/01/06/p/dre/pt/ htm (accessed October 17, 2020).

Hammond, P., Macleod, K., Berggren, P., Borchers, D., Cañadas, A., Desportes, G., et al. (2013). Cetacean abundance and distribution in European Atlantic shelf waters to inform conservation and management. Biol. Conserv. 164, 107-122. doi: 10.1016/j.biocon.2013.04.010

iNaturalist (2021). iNaturalist. Available online at: www.inaturalist.org (accessed March 19, 2021).

IUCN Red List (2021). International Union for Conservation of Nature. Available online at: www.iucnredlist.org (accessed July 3, 2021).

Jarić, I., Correia, R. A., Brook, B. W., Buettel, J. C., Courchamp, F., Di Minin, E., et al. (2020). iEcology: harnessing large online resources to generate ecological insights. Trends Ecol. Evol. 35, 630-639. doi: 10.1016/j.tree.2020.03.003 
Laborde, M., Cid, A., and Castro, J. (2019). "Important area of conservation for cetaceans in southern Iberian Peninsula," in Proceedings of the World Marine Mammal Conference 2019, eds M. Gazo, C. A. Chicote, A. Pabst, and M. Aqcuarone (Barcelona), 391.

Laborde, M. I., Fonseca, C., Candeias, J., Galego, S., and Castro, J. (2012). "Common dolphin (Delphinus delphis) response to boating pressure in the south coast of Portugal," in Proceedings of the 26th Conference of the European Cetacean Society, Information and Ideas Worth Sharing Galway, eds B. McGovern, S. Berrow, E. McKeogh, and I. O'Connor (Galway: European Cetacean Society), 300. doi: 10.1016/s0016-6480(02)00058-8

Laborde, M., Cid, A., Fonseca, C., and Castro, J. (2015). "Baleen whales in Southern Portugal: new insights," in Proceedings of the 29th Conference of the European Cetacean Society, Marine Mammal Conservation From Local to Global St. Julian's Bay, eds A. Vella, N. Vella, and C. M. Mifsud (St. Julian's Bay: European Cetacean Society), 209.

Laborde, M., Gonçalves, J., Candeias, J., Prista, G., and Castro, J. (2011). Risso's Dolphin (Grampus griseus) Photo-Identification Catalogue in Southern Portugal. Available online at: www.researchgate.net (accessed December 28, 2020).

Li, W.-T., Chou, L.-S., Chiou, H.-Y., Chen, I.-H., and Yang, W.-C. (2021). Analyzing 13 years of cetacean strandings: multiple stressors to cetaceans in Taiwanese waters and their implications for conservation and future research. Front. Mar. Sci. 8:606722. doi: 10.3389/fmars.2021.606722

Lopreite, M., Panzarasa, P., Puliga, M., and Riccaboni, M. (2021). Early warnings of COVID-19 outbreaks across Europe from social media. Sci. Rep. 11:2147.

MacEwan, C., Bishop, P., Henriques, A. C., Castro, J., Cid, A., and Laborde, M. I. (2016). "High-intensity dolphin-watching in southern Portuguese waters," in Proceedings of the 30th Conference of the European Cetacean Society, Into the Deep: Research and Conservation on Oceanic Marine Mammals, eds L. Freitas, and C. Ribeiro (Machico), 191.

Magalhães, S. (2016). "Bottlenose dolphins (Tursiops truncatus) occurring in coastal waters of SW Portugal: resident or transient?" in Proceedings of the 30th Conference of the European Cetacean Society, Into the Deep: Research and Conservation on Oceanic Marine Mammals, eds L. Freitas and C. Ribeiro (Machico), 140.

Magalhães, S., and Claro, B. (2013). "Occurrence and distribution of bottlenose dolphins Tursiops truncatus in the coastal area of southwest Portugal," in Proceedings of the 27th Conference of the European Cetacean Society, Interdisciplinary Approaches in the Study of Marine Mammals, eds M. Sequeira, C. Brito, I. Carvalho, C. Picanço, R. Amaral, T. Marques, et al. (Setúbal), 167.

Marçalo, A., Giménez, J., Nicolau, L., Frois, J., Ferreira, M., Sequeira, M., et al. (2021). Stranding patterns and feeding ecology of striped dolphins, Stenella coeruleoalba, in Western Iberia (1981-2014). J. Sea Res. 169:101996. doi: 10. 1016/j.seares.2021.101996

Marçalo, A., Katara, I., Feijó, D., Araújo, H., Oliveira, I., Santos, J., et al. (2015). Quantification of interactions between the Portuguese sardine purse-seine fishery and cetaceans. ICES J. Mar. Sci. 72, 2438-2449. doi: 10.1093/icesjms/ fsv076

Marçalo, A., Nicolau, L., Giménez, J., Ferreira, M., Santos, J., Araújo, H., et al. (2018). Feeding ecology of the common dolphin (Delphinus delphis) in Western Iberian waters: has the decline in sardine (Sardina pilchardus) affected dolphin diet? Mar. Biol. 165:44.

Martin, A. R., and Walker, F. J. (1997). Sighting of a right whale (Eubalaena glacialis) with calf off S. W. Portugal. Mar. Mamm. Sci. 13, 139-140. doi: 10.1111/j.1748-7692.1997.tb00617.x

Moura, A. E., Sillero, N., and Rodrigues, A. (2012). Common dolphin (Delphinus delphis) habitat preferences using data from two platforms of opportunity. Acta Oecol. 38, 24-32. doi: 10.1016/j.actao.2011.08.006

Moura, A., Silva, S. E., Spea, Correia, A. M., Sousa-Pinto, I., Gil, A., et al. (2019). "Mamíferos marinhos," in Atlas de Mamíferos de Portugal, eds J. Bencatel, H. Sabino-Marques, F. Álvares, A. E. Moura, and A. M. Barbosa (Évora: Universidade de Évora).

Moura, D., Albardeiro, L., Veiga-Pires, C., Boski, T., and Tigano, E. (2006). Morphological features and processes in the central Algarve rocky coast (South Portugal). Geomorphology 81, 345-360. doi: 10.1016/j.geomorph.2006.04.014

Mwango'mbe, M. G., Spilsbury, J., Trott, S., Nyunja, J., Wambiji, N., Collins, T., et al. (2021). Cetacean research and citizen science in Kenya. Front. Mar. Sci. 8:642399. doi: 10.3389/fmars.2021.642399
Obar, J. A., and Wildman, S. (2015). Social media definition and the governance challenge: an introduction to the special issue. Telecomm. Policy 39, 745-750. doi: 10.1016/j.telpol.2015.07.014

Ocean Vibes Algarve (2021). Ocean Vibes Algarve. Available online at: www.instagram.com/p/CS7msYrIjmT (accessed August 24, 2021).

Pace, D., Giacomini, G., Campana, I., Paraboschi, M., Pellegrino, G., Silvestri, M., et al. (2019). An integrated approach for cetacean knowledge and conservation in the central Mediterranean Sea using research and social media data sources. Aquat. Conserv. 29, 1302-1323. doi: 10.1002/aqc.3117

Pereira, A., Martinho, F., Carvalho, I., Magalhães, S., and Brito, C. (2012). Orca (Orcinus orca) Occurrence off the Portuguese Continental Coast: Data Compilation from Distinct Historical and Recent Sources. Available online at: www.researchgate.net (accessed October 17, 2020).

Poças, A., and Magalhães, S. (2019). "Spatial and temporal variation occurrence of Risso's dolphin (Grampus griseus) in southwestern coast of Portugal," in Proceedings of the World Marine Mammal Conference 2019, eds M. Gazo, C. A. Chicote, A. Pabst, and M. Aqcuarone (Barcelona), 566.

Relvas, P., and Barton, E. D. (2002). Mesoscale patterns in the Cape São Vicente (Iberian Peninsula) upwelling region. J. Geophys. Res. Oceans 107, 28-21.

Robbins, J. R., Babey, L., and Embling, C. B. (2020). Citizen science in the marine environment: a case-study estimating common dolphin densities in the North-East Atlantic. PeerJ 8:e8335. doi: 10.7717/peerj.8335

Rodriguez, L. K., Fandel, A. D., Colbert, B. R., Testa, J. C., and Bailey, H. (2021). Spatial and temporal variation in the occurrence of bottlenose dolphins in the Chesapeake Bay, USA, using citizen science sighting data. PLoS One 16:e0251637. doi: 10.1371/journal.pone.0251637

Sabino-Marques, H. (2005). Arrojamentos de Cetáceos na Costa Continental Portuguesa. B.Sc Dissertation. Évora: University of Évora.

Sequeira, M., Elejabeitia, C., Silva, M., Dinis, A., Stephanis, R., Urquiola, E., et al. (2009). Review of whale-watching activities in mainland Portugal, the Azores, Madeira and Canary archipelagos and the Strait of Gibraltar. J. Cetacean Res. Manage. 1-40.

Silva, M., and Sequeira, M. (2003). Patterns in the mortality of common dolphins (Delphinus delphis) on the Portuguese coast, using stranding data records, 1975-1998. Aquat. Mamm. 29, 88-98. doi: 10.1578/01675420310102 3924

Sousa, A., and Brito, C. (2012). Historical strandings of cetaceans on the Portuguese coast: anecdotes, people and naturalists. Mar. Biodivers. Rec. 5:e2.

Stekke, V., Gauffier, P., Verborgh, P., Besugo, A., Prista, G., Gonçalves, J., et al. (2011). “Abundance and distribution of Risso's dolphin in the Southwest Iberian Peninsula," in Proceedings of the 25th Conference of the European Cetacean Society, Long-term Datasets on Marine Mammals: Learning From the Past to Manage the Future, Cadiz, eds P. Gauffier and P. Verborgh (Cadiz: European Cetacean Society), 225.

Toivonen, T., Heikinheimo, V., Fink, C., Hausmann, A., Hiippala, T., Järv, O., et al. (2019). Social media data for conservation science: a methodological overview. Biol. Conserv. 233, 298-315. doi: 10.1016/j.biocon.2019.01.023

Vieira, S. (2017). Distribution and Abundance of Bottlenose Dolphins (Tursiops truncatus) on the South Coast of Portugal. M.Sc dissertation. Lisbon: University of Lisbon.

Conflict of Interest: The authors declare that the research was conducted in the absence of any commercial or financial relationships that could be construed as a potential conflict of interest.

Publisher's Note: All claims expressed in this article are solely those of the authors and do not necessarily represent those of their affiliated organizations, or those of the publisher, the editors and the reviewers. Any product that may be evaluated in this article, or claim that may be made by its manufacturer, is not guaranteed or endorsed by the publisher.

Copyright (๑) 2021 Morais, Afonso and Dias. This is an open-access article distributed under the terms of the Creative Commons Attribution License (CC BY). The use, distribution or reproduction in other forums is permitted, provided the original author(s) and the copyright owner(s) are credited and that the original publication in this journal is cited, in accordance with accepted academic practice. No use, distribution or reproduction is permitted which does not comply with these terms. 